\title{
The First Record of GregarinatypographiFuchs (Protista: Apicomplexa: Gregarinidae) from the European Spruce Bark Beetle, Ips typographus (Linnaeus) (Coleoptera: Curculionidae, Scolytinae) in Turkey
}

\section{Türkiye'de Ips typographus (Linnaeus) (Coleoptera: Curculionidae, Scolytinae)'dan Gregarina typographi Fuchs (Sporozoa, Gregarinidae)'nin İlk Kaydı}

\author{
Mustafa YAMAN ${ }^{1}$, Hilal BAKi² \\ 1 Department of Biology, Science-Literature Faculty, Karadeniz Technical University, Trabzon \\ ${ }^{2}$ Department of Biology, Science-Literature Faculty, Ordu University, Ordu Turkey
}

\section{ABSTRACT}

Objective: Aim of this study is determining pathogens of Ips typographus from Eastern Black Sea Region in Turkey.

Methods: Samples collected from the field were taken to laboratuar as soon as possible. Microscopic examination was completed by dissection with Ringer's solution.

Results: 780 Ips typographus beetles from Giresun, Rize and Artvin were examined. Gregarines were observed in the populations of I. typographus in the three regions. 27 of 780 beetles were found to be infected by the Gregarina typographi. Total rate of infection was $3.4 \%$ in three localities. During the study several life stages of the gregarine pathogen (trophozoite, gamont, Cysts and associative form) were observed. Gametocysts were spherical and from 77 to $85 \mu \mathrm{m}$ in diameter. Total lengths of solitary gamonts were measured. from 90 to $155 \mu \mathrm{m}$. Measurements of gamonts and gametocysts of $G$. typographi were given and compared with other gregarines isolated from bark beetles. This pathogen is described as Gregarina typographi.

Conclusion: The gregarine pathogen of Ips typographus is reported from Turkey for the first time. (Turkiye Parazitol Derg 2010; 34: 179-82) Key Words: Gregarine pathogen, Ips typographus, Gregarina typographi

Received: $13.04 .2010 \quad$ Accepted: 19.07.2010

ÖZET

Amaç: Doğu Karadeniz bölgesinde yayılış gösteren Ips typographus türündeki patojen varlığının belirlenmesi amaçlanmıştır.

Yöntemler: Araziden toplanan örnekler en kısa sürede labaoratuvara getirilmiştir. Ringer solüsyonu ile diseksiyon yapılarak mikroskobik incelemeleri tamamlanmıştır.

Bulgular: Artvin, Rize ve Giresun illerinden toplam 780 adet Ips typographus örneği incelenmiştir. Her 3 ilde de gregarin patojeninin varlığı tespit edilmiştir. Disekte edilen 780 böcekten 27 tanesinde gregarin enfeksiyonuna rastlanılmıştır. Enfeksiyon yüzdesi \% 3,4 tür. Çalışma boyunca patojene ait çeşitli hayat safhaları (trofozoit, gamont, kist ve şizigi) gözlenmiştir. Gametokistler küremsi şekilli ve 77-85 $\mu$ m çapında ölçülmüştür. Gamontların total uzunluğu min. $90 \mu \mathrm{m}$, max. $155 \mu \mathrm{m}$ olarak ölçülmüştür. Patojenin vücut kısımlarına ait gerekli ölçümler karşılaştırılarak karakterizasyonu yapılmış ve Gregarina typographi olarak tanımlanmıştır.

Sonuç: Bu çalışmada, Ips typographus'tan G. typographi (Apicomplexa: Gregarinidae) patojeninin varlığı ülkemiz için ilk kez kaydedilmiş̧tir. (Turkiye Parazitol Derg 2010; 34: 179-82)

Anahtar Sözcükler: Gregarin patojeni, Ips typographus, Gregarina typographi

Geliş Tarihi: 13.04.2010

Kabul Tarihi: 19.07.2010

Address for Correspondence/Yazışma Adresi: Dr. Mustafa Yaman, Department of Biology, Science-Literature Faculty, Karadeniz Technical University, Trabzon, Turkey Phone: +90 4623772586 E-mail: yaman@ktu.edu.tr doi:10.5152/tpd.2010.08 


\section{INTRODUCTION}

There are many economically harmful bark beetles in Turkey (1). The European spruce bark beetle Ips typographus is one. This pest is causing damage to Picea orientalis forests in the eastern Black Sea Region, leading to severe economic loss. In order to control this important pest, methods such as pheromone traps, chemical pesticides and mechanical control strategies have been used up to the present. These methods are inadequate because undulating land conditions make the application of these methods difficult and expensive. Apparently, chemicals have harmful effects on the environment, building up in the water, soil and living organisms. In addition, another disadvantage of using chemicals is that they destroy the natural enemies of target organisms. Natural enemies are very important in biological control. For this reason, many studies have been carried out on using natural enemies in biological control (2-5). In recent years, microorganisms have come in to prominence as biological control agents. The use of microorganisms as pathogens may very effective. Pathogens of Ips typographus are known from different parts of the world (6-12), but there is a lack of knowledge about the pathogens in Turkey. In the present paper, a gregarine pathogen of $I$. typographus from Turkey is reported for the first time.

\section{MATERIALS AND METHODS}

Adult I. typographus specimens were collected from spruce (Picea orientalis) forests using pheromone traps in Giresun, Rize and Artvin (Turkey), from May to August in 2009. Each beetle was dissected in a Ringer solution and its intestine was examined microscopically at magnifications of 400x to 1000x. Observed pathogens were measured and photographed using an Olympus BX 51 microscope with a DP-25 digital camera and DP2-BSW Soft Imaging System. The following abbreviations, according to Lipa (13), Geus (14) and Clopton (15) are used to identify the gregarine pathogen in this paper: $T L=$ total length; $L P=$ length of protomerite; $L D=$ length of deutomerite; $W P=$ width of protomerite; $\mathrm{WO}=$ width of deutomerite; $L P: T L=$ ratio of the length of protomerite to total length; WP:WD=ratio of the width of protomerite to the width of deutomerite; and WP:TL= ratio of the width of protomerite to total length. The systematic examination of the parasite was made by comparing the same or systematically close species given by Lipa (13) and Geus (14).

\section{RESULTS}

A gregarine pathogen was found in Ips typographus; Gregarina typographi FUCHS (Protista, Eugregarinida). Gregarines were observed in the populations of $I$. typographus collected from three localities (Giresun, Rize and Artvin). During the study, several life stages of the gregarine pathogen, such as trophozoite with epimerite (Figure 1A), gamont (Figure 1B), associative form previous to the cyst (Figure 1C), precyst (Figure 1D) and cyst (Figure 1E) were observed. Measurements (in $\mu \mathrm{m}$ ) of gregarine gamonts are given Table 1. Gametocysts were spherical and from 77 to $85 \mu \mathrm{m}$ in diameter (Figure 1E). Its gamonts were found in the mid-gut lumen. Gamonts were oval to elongated and solitary.

04 of 135 beetles examined from Giresun, 06 of 177 beetles from Rize, and 17 of 468 beetles from Artvin were found to be infected by the gregarine pathogen. Infection rates were found as $2.9 \%$ in Giresun, 3.3\% in Rize and 3.6\% in Artvin. Total rate of infection was $3.4 \%$ for the three localities.
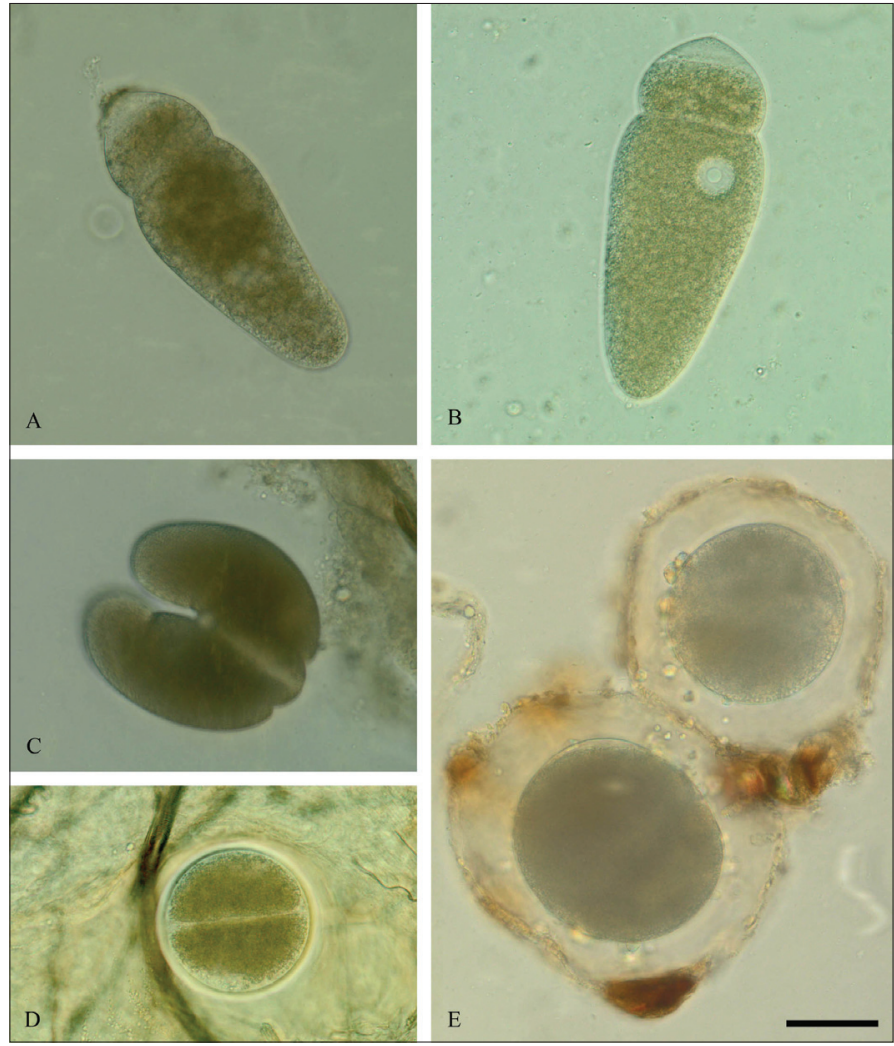

D

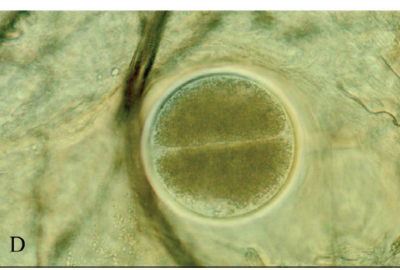

Figure 1. Trophozoite (A), Gamont (B), Associative form, previous of cyst (C), Precyst (D), Cyst (E) of the G. typographi. (Bar $50 \mu \mathrm{m}$ )

\section{DISCUSSION}

In the literature there are several reports on the gregarine pathogen of bark beetles $(6,7,13,16,17)$. The first gregarine pathogen record from bark beetles in Turkey is Gregarina typographi from Ips sexdentatus (18). The gregarine presented in the present study is the second record from bark beetles in Turkey, but the first gregarine pathogen record from Ips typographus in Turkey. The pathogen shows similarities to Gregarina typographi Fuchs, recorded by Fuchs (6) from Ips typographus for the first time, in terms of its characteristics identified with the genus Gregarina (Table 2). The gregarine in the present study is apparently similar to $G$. typographi in its morphological characters. In the present study, total lengths of solitary gamonts were measured from 90 to $155 \mu \mathrm{m}$. Lipa (13) reported that the total length of solitary gamonts measured from 78 to $118 \mu \mathrm{m}$ and Takov et al. (19) observed gamonts between 32.5-193.8 $\mu \mathrm{m}$ for G. typographi from Ips typographus. Yaman (18) reported that solitary gamont total length measured from 80 to $275 \mu \mathrm{m}$. Lipa (13), Purrini (17), Wegensteiner et al. (7) and Takov et al. (19) recorded this pathogen from the same host.

There are several reports in the literature about the occurrence of G. typographi from two Ips species (I. sexdentatus and I. typographus) which are the most economically important in Turkey. I. sexdentatus and I. typographus are from the family Curculionidae (Coleoptera) and they share the same terrestrial habitat, even the same tree (Picea orientalis) in the Eastern Black Sea Region, therefore they also share pathogens. According to these facts, G. typographi has two different hosts which are I. sexdentatus and I. typographus in Turkey. G. typographi was 
Table 1. Measurements of gamonts of Gregarina typographi in Ips typographus (in $\mu \mathrm{m}$ ).

\begin{tabular}{|c|c|c|c|c|c|c|c|c|}
\hline & TL & LP & LD & WP & WD & LP:TL & WP:WD & WP:LP \\
\hline \multirow[t]{24}{*}{ Gamonts } & 150.32 & 41.44 & 108.88 & 43.72 & 42.23 & 0.28 & 1.04 & 1.06 \\
\hline & 91.25 & 24.76 & 66.49 & 39.15 & 45.38 & 0.27 & 0.86 & 1.58 \\
\hline & 102.88 & 25.82 & 77.06 & 40 & 41.21 & 0.25 & 0.97 & 1.55 \\
\hline & 109.78 & 30.9 & 78.88 & 30.33 & 35.96 & 0.28 & 0.84 & 0.98 \\
\hline & 104.73 & 31.25 & 73.48 & 41.02 & 41.23 & 0.30 & 0.99 & 1.31 \\
\hline & 138.44 & 31.67 & 106.77 & 39.54 & 39.55 & 0.23 & 1.00 & 1.25 \\
\hline & 143.33 & 40.64 & 102.69 & 36.88 & 37.27 & 0.28 & 0.99 & 0.91 \\
\hline & 155.56 & 36.25 & 119.31 & 49.53 & 66.5 & 0.23 & 0.74 & 1.37 \\
\hline & 128.27 & 40.65 & 87.62 & 41.65 & 41.94 & 0.32 & 0.99 & 1.02 \\
\hline & 90.73 & 28.93 & 61.8 & 36.35 & 44.35 & 0.32 & 0.82 & 1.26 \\
\hline & 154.79 & 37.84 & 116.95 & 52.26 & 66.84 & 0.24 & 0.78 & 1.38 \\
\hline & 95.69 & 24.43 & 71.26 & 26.67 & 32.77 & 0.26 & 0.81 & 1.09 \\
\hline & 118.51 & 27.63 & 90.88 & 40.26 & 37.54 & 0.23 & 1.07 & 1.46 \\
\hline & 95.94 & 23.66 & 72.28 & 33.55 & 38.01 & 0.25 & 0.88 & 1.42 \\
\hline & 115.69 & 29.33 & 86.36 & 36.72 & 43.57 & 0.25 & 0.84 & 1.25 \\
\hline & 146.61 & 45.77 & 100.84 & 41 & 38.01 & 0.31 & 1.08 & 0.90 \\
\hline & 101.4 & 27.79 & 73.61 & 37.27 & 35.77 & 0.27 & 1.04 & 1.34 \\
\hline & 98.13 & 20.62 & 77.51 & 32.49 & 35.87 & 0.21 & 0.91 & 1.58 \\
\hline & 115.93 & 28.1 & 87.83 & 41.2 & 39.64 & 0.24 & 1.04 & 1.47 \\
\hline & 118.67 & 26.06 & 92.61 & 25.78 & 34.84 & 0.22 & 0.74 & 0.99 \\
\hline & 128.87 & 26.53 & 102.34 & 41.24 & 40.41 & 0.21 & 1.02 & 1.55 \\
\hline & 117.43 & 35.91 & 81.52 & 37.05 & 40.61 & 0.31 & 0.91 & 1.03 \\
\hline & 95.71 & 20.61 & 75.1 & 33.65 & 37.04 & 0.22 & 0.91 & 1.63 \\
\hline & 146.43 & 42.46 & 103.97 & 39.59 & 36.5 & 0.29 & 1.08 & 0.93 \\
\hline Mean & 119.37 & 31.21 & 88.16 & 38.20 & 41.37 & 0.26 & 0.93 & 1.26 \\
\hline Min. & 90.73 & 20.61 & 61.8 & 25.78 & 32.77 & 0.21 & 0.74 & 0.90 \\
\hline Max. & 155.56 & 45.77 & 119.31 & 52.26 & 66.84 & 0.32 & 1.08 & 1.63 \\
\hline SD. & 21.64 & 7.23 & 16.28 & 6.07 & 8.40 & 0.03 & 0.11 & 0.24 \\
\hline
\end{tabular}

Table 2. The comparative characters of gregarines observed in beetles (Coleoptera) compared to Gregarina typographi Fuchs (mm).

\begin{tabular}{|l|c|c|c|c|c|}
\hline Characters & G. typographi & G. typographi Fuchs & G. typographi & G. typographi & G. typographi \\
\hline TLa $^{a}$ & $80-275$ & $78-118$ & $32.5-193.8$ & $55-237.5$ & $90-155$ \\
\hline LP:TLa $^{\text {a }}$ & $1: 2.7-5.3$ & $1: 2.2-5$ & $1: 0.14-0.49$ & $1: 0.09-0.38$ & $1: 0.21-0.32$ \\
\hline WP:WD & $1: 1.1-1.3$ & $1: 1.1-2$ & $1: 0.63-1.13$ & $1: 0.22-1.8$ & $1: 0.74-1.08$ \\
\hline Gametocyst & Spherical 90 to 100 & $\ldots \ldots \ldots \ldots$ & $\ldots \ldots \ldots \ldots$ & $\ldots \ldots \ldots$ & Spherical 77 to 85 \\
\hline Host & Ips sexdentatus & Ips typographus & Ips typographus & Ips sexdentatus & Ips typographus \\
\hline Reference & 18 & 13 & 19 & 19 & Present study \\
\hline a: minimal and maximal: TL; total length; LP:TL: ratio of the length of protomerite to total length; WP:WD: ratio of the width of protomerite to the width of deutomerite. \\
\hline
\end{tabular}


reported from I. sexdentatus by several authors (16-19). The occurrence of G. typographi from I. sexdentatus i was reported for the first time from Turkey by Yaman (18) and G. typographi from I. typographus is reported for the first time from Turkey in the present study.

G. typographi was found from I. typographus, I. sexdentatus and I. acuminatus in Bulgaria, infection rates were found as $10.1 \%$ for I. typographus, $27.4 \%$ for I. sexdentatus and $11.8 \%$ for I. acuminatus (19). Händel et al. (2) found $0.8-59.4 \%$ infection for G. typographi in I. typographus and Wegensteiner \& Weiser (20) reported $6.3 \%$ infection in the same host in Austria. Wegensteiner et al. (21) reported $16.7-45.5 \%$ infection rates in I. sexdentatus in Austria. Wegensteiner \& Weiser (22) reported this pathogen from I. typographus in Germany and its infection rate was $11 \%$. Holusa et al. (11) reported it from I. typographus and I. duplicatus in Czech Republic with the infection rates, $5 \%$ and $\leq 5 \%$ respectively. Kereselidze \& Wegensteiner (23) , Kereselidze et al., (10) and Burjanadze \& Goginashvili (12) reported G. typographi from I. typographus in Georgia, the pathogen infection rates were $23.2-48.6 \%$ for 2005, 24\% for 2007 and 7.5-49.5\% for 2009 from I typographus. Takov et al. (9) reported the same pathogen from 1. typographus in Bulgaria, max total infection rate was $45.2 \%$ and min total infection rate was 5.3\% from four different areas in this report. Yaman (18) reported that this pathogen causes $6 \%$ infection in I. sexdentatus in Turkey. Ünal et al. (24) found $25.8 \%$ infection in the same host. All results show that $G$. typographi is present in neighbor countries, Bulgaria, Georgia and Turkey, indicating distribution of this pathogen. In addition to this, Germany, Austria and Czech Republic are neighbor countries too. Although, infection rate of $G$. typographi is high in Georgia and Bulgaria, it is low in Turkey.

Ips typographus is important pest in spruce forests for Turkey. These insects cause great economic loss in oriental spruce forest in Black Sea Region. Tanada \& Kaya (25) reported that the pathological effects of gregarines are generally weak. However the gregarine pathogen may play an important role in the biological control of bark beetles by reducing the life span and reproductive potential of the host (18). So, we need much more studies in this subject.

\section{Acknowledgements}

This study was supported by The Research Foundation of Karadeniz Technical University (Project num.: 2007.111.004.4).

\section{Conflict of Interest}

No conflict of interest was declared by the authors.

\section{REFERENCES}

1. Eroglu M. Orman Entomolojisi. Ders Notu, Trabzon,2002; p.140.

2. Händel U, Wegensteiner R, Weiser J, Zizka Z, 2003. Occurrence of pathogens in associated living bark beetles (Col., Scolytidae) from different spruce stands in Austria. Journal of Pest Science, 76: 22-32.

3. Wegensteiner R. Pathogens in bark beetles, In: Bark and wood boring insects in living trees in Europe, a synthesis. Kluwer Academic Publishers. 2004; 291-313.

4. Yaman M, Radek R. Helicosporidium infection of the great Europen spruce bark beetle, Dendroctonus micans (Coleoptera. Scolytidae). European Journal of Protistology, 2005; 41: 203-7.

5. Yaman M, Radek R. Identifi cation, distribution and occurence of the ascomycete fungus Metschnikowia typographi in the great spruce bark beetle, Dendroctonus micans. Folia Microbiologica, 2008; 53: 427-32.

6. Fuchs G. Die Naturgeschichte der Nematoden und einiger anderer Parasiten 1. des Ips typographus L. 2. des Hylobius abietis L. Zool. Jb, Abt. Syst,1915; 38: 109-222.
7. Wegensteiner R, Weiser J, Fohrer E. Observations on the occurrence of pathogens in the bark beetle Ips typographus L. (Coleoptera. Scolytidae). Journal of Applied Entomology, 1996; 120: 199-204.

8. Weiser J, Wegensteiner R, Zizka Z. Unikaryon montanum sp.n. (Protista: Microspora), a new pathogen of the spruce bark beetle lps typographus (Coleoptera: Scolytidae). Folia Parasitol, 1998; 45: 191-5.

9. Takov D, Pilarska D, Wegensteiner R. Entomopathogens in Ips typographus (Coleoptera: Scolytidae) from Several Spruce Stands in Bulgaria, Acta Zoologica Bulgarica,2006; 58: 409-20.

10. Kereselidze M, Wegensteiner R, Goginashvili N, Tvaradze M. Natural enemies of Ips typographus (Coleoptera: Scolytidae) from spruce stands in Georgia. Proceedings of IUFRO Meeting. September, 2007: 9-14.

11. Holusa J, Weiser J, Zizka Z. Pathogens of the spruce bark beetles Ips typographus and Ips duplicates. Central Europen Journal of Biology, 2009; 4: 567-73.

12. Burjanadze M, Goginashvili N. Occurence of Pathogens and Nematodes in the Spruce Bark Beetles, Ips typographus (Coleoptera:Scolytidae) in Borjomi Gorge, Bulletin of the Georgian National Academy of Sciences,2009; 3: 1 .

13. Lipa JJ. Studies on gregarines (Gregarinomorpha) of arthropods in Poland, Acta Protozoologica, 1967; 5: 97-179

14. Geus A. Sporentierchen Sporoza, Die Gregarinida: Die Tierwelt Deutschlands. Teil 57, VEB Gustav Fischer. Jena.1969; pp. 608

15. Clopton RE. Standard nomenclature and metrics of plane shapes for use in gregarine taxonomy. Comparative Parasitology, 2004; 71: 130-40.

16. Theodorides J. Parasites et phoretiques de caleopteres et de myriapodes de Richelieu (Indre-et-Loire), Ann. de Parasitologie, XXXV, 1973; 488-503.

17. Purrini K. Protozoen als Krankheitserreger bei einigen Borkenkaferarten (Col., Scolytidae) im Konigsee-Gebiet, Oberbayern. Anz Schadlingskde. Pfl anzenschutz. Umweltschutz, 1978; 51: 171-5.

18. Yaman M. Gregarina typographi Fuchs, a Gregarine Pathogen of the Six-Toothed Pine Bark Beetle, Ips sexdentatus (Boerner) (Coleoptera: Curculionidae, Scolytinae) in Turkey. Turk Journal of Zoology, 2007; 31: 359-63.

19. Takov D, Doyche D, Wegensteiner R, Pilarska D. Study of Bark Beetle (Coleoptera, Scolytidae) Pathogens from Coniferous stands in Bulgaria. Acta Zoologica Bulgarica, 2007; 59: 87-96.

20. Wegensteiner R, Weiser J. Annual variation of pathogen occurrence and pathogen prevalence in lps typographus (Coleoptera. Scolytidae) from the BOKU University Forest Demonstration Centre. Journal of Pest Science, 2004; 78: 221-8.

21. Wegensteiner R, Pernek M, Weiser J. Occurrence of Gregarina typographi (Sporozoa, Gregarinidae) and of Metschnikowia typographi (Ascomycota, Metschnikowiaceae) in Ips sexdentatus (Col., Scolytidae) from Austria. Proceedings of the 10th European Meeting: Invertebrate pathogens in biological control: Present and Future at Locorotondo. June, 2005; 23-9.

22. Wegensteiner R, Weiser J. Untersuchungen zum Auftreten von Pathogenen bei lps typographus (Col., Scol.) aus einem Naturschutzgebiet im Schwarzwald (Baden Württenberg) (in German). Anz Schädl, Pfl anz, Umwelt, 1996; 69: 162-7.

23. Kereselidze M, Wegensteiner R. Occurrence of pathogens and parasites in Ips typographus L. from spruce stands (Picea orientalis L.) in Georgia. 10th European Meeting IOBC/wprs Working Group. Locorotondo(Bari)-Italy, 2005

24. Ünal S, Yaman M, Tosun O, Aydın Ç. Occurrence of Gregarina typographi (Apicomplexa, Gregarinidae) and Metschnikowia typographi (Ascomycota, Metschnikowiaceae) in Ips sexdentatus (Coleoptera: Curculionidae, Scolytinae) Populations in Kastamonu (Turkey). Journal of Animal and Veterinary Advances, 2009; 8: 2687-91.

25. Tanada Y, Kaya HK. Protozoan infection: Apicomplexa, Microspora. In: Insect Pathology, Academic Press, San Diego, 1993; 414-58. 